\title{
EFFECT OF ADDITION OF CONCENTRATED PROTEINS AND SEMINAL PLASMA LOW MOLECULAR WEIGHT PROTEINS IN FREEZING AND THAWING OF EQUINE SEMEN
}

\author{
Fagundes, B. ${ }^{1 *}$; Van Tilburg, M.F. ${ }^{2}$; Souza, G.V. ${ }^{3}$; Caiado, J.R.C. ${ }^{3}$; Barreto, M.A.P. ${ }^{3}$; Silva, \\ J.F.S. ${ }^{3}$
}

http://dx.doi.org/10.18571/acbm.002

\begin{abstract}
Difficulties in obtaining equine frozen semen with potential fertility are recognized. This study was designed to investigate the effect of seminal plasma on frozen/thawing of eight stallion semen from different breed using the following treatments: Seminal plasma with ten-fold concentrated proteins with molecular weight above $10 \mathrm{kDa}$ on frozen extender; Part of seminal plasma with proteins under $10 \mathrm{kDa}$ on frozen extender; Conventional freezing, using whole seminal plasma on frozen extender. Using the parameter of $30 \%$ of seminal motility post-thawing as index of good freezability, it was verified an increased percentage of stallions that presented good freezability when semen was frozen with seminal plasma containing ten-fold concentrated proteins with molecular weight above $10 \mathrm{kDa}$ on frozen extender. These results, suggested the use of seminal plasma concentrated proteins from own stallion to freezing/thawing semen.
\end{abstract}

Keywords: Seminal plasma, spermatozoa, freezing, thawing, horse

\footnotetext{
${ }^{1}$ Department of Medicine, Iguaçu University, Itaperuna, Brazil

${ }^{2}$ Department of Animal Science, Federal University of Ceará, Fortaleza, Brazil

${ }^{3}$ Department of Reproduction and Animal Genetic lmprovement UENF, Campos dos

Goytacazes, Brazil

Autor para correspondência. b.fagundes@yahoo.com.br
} 
Fagundes, B.; van Tilburg, M.F.; Souza, G.V.; Caiado, J.R.C.; Barreto, M.A.P.; Silva, J.F.S.

Effect of addition of concentrated proteins and seminal plasma low of addition of concentrated proteins and seminal plasma low molecular

weight proteins in freezing and thawing of equine semen.

\section{INTRODUCTION}

Several studies from all over the world aimed to establish protocols for freezing to ensure a better quality of equine semen through modification of procedures employed in cryopreservation (AURICH, J. E. et al, 1996; KLUG et al, 1992).

Protocols of cryopreservation of equine spermatozoa are not standardized and the success of this preservation varies substantially. In general, the success rates are lower than in other domestic species. One of the requirements for the effectiveness for preservation of stallion semen is the initial high quality (SAMPER, 1995). Differences exist in freezability of equine semen among different ejaculated samples from the same stallion (KLUG et al, 1992). This variability in the spermatozoa capacity from different stallions in tolerating freezing and thawing processes is one of the most important reasons for the fact that equine semen is not used in large scale (SAMPER, 1995). Only 25\% of stallions will have pregnancy rates comparable to fresh semen or natural coupling when inseminated in healthy mares and in the appropriated moment (AMANN \& PICKETT,1987; VIDAMENT et al, 1997). A survey current methods for stallion semen cryopreservation widely commercially used considered $30 \%$ of motility acceptable in the post-thaw evaluation criteria (SAMPER, 1995).

Seminal plasma exerts a stimulating effect in seminal motility at the moment of ejaculation, besides acting as extender and vehicle for spermatozoa. That is partially due to the effect of dilution, however the activation of spermatozoa by seminal plasma is also due to the presence of specific substances in different secretions of accessory glands (MAXWELL \& JOHNSON, 1999). The composition of seminal plasma varies in agreement with species, intervals among ejaculations and health of the animal (CATT et al, 1997). In spite of the beneficial osmotic effects of extenders, the dilution of semen also removes adsorbed proteins, natural antioxidants, and other components present in seminal plasma requested for maintenance of membrane integrity and for spermatozoa action (CAAT et al, 1997). The partial removal of these components during dilution could triggered differences of loadings among spermatozoa, resulting in agglutination "head with head", a problem that could be avoided with the addition of proteins, as well as, the bovine serum albumin (BSA), or seminal plasma to the media (MAXWELL \& JOHNSON, 1999). Thus, these protocols using the acquisition of seminal plasma proteins reverts the harmful effect of thermal shock on spermatic membrane of sheep (BARRIOS et al, 2000).

Several studies suggest that seminal plasma contains factors that influence fertility in males. Some of these factors have been isolated, such as ions, proteins and lipids. Among these, proteins are the most studied compound. Presence, absence or protein concentration in seminal plasma are responsible for the effects of this fluid in spermatic fertility (HENAULT \& KILLIAN, 1996). The presence of seminal plasma increases the resistance of spermatozoa to thermal shock and its capacity of surviving after freezing and thawing (PURSEL \& JOHNSON, 1975). The interaction of proteins of seminal plasma with spermatozoa should influence its fertilizing capacity and protection of spermatic membrane from thermal shocks (BARRIOS et al, 2000).

It has been reported that high concentration of proteins with low molecular weight cause increase in spermatic membrane permeability, promoting thermal shock and cell injury during freezing and thawing (GARCÍA \& GRAHAN, 1987). Compounds containing proteins with low molecular weight induce damages on the spermatozoa, such as, the removal of those proteins of seminal plasma is important to survival and quality of spermatozoa (AL-SOMAI et al, 1994a; AL-SOMAI et al, 1994b).

Indeed, the seminal plasma of equine is almost fully removed during semen freezing, and the pregnancy rates after insemination with these semen previously frozen remains to be 
improve (RIGBY et al, 1999). The difference between seminal plasma protein concentration from bovine and equine, and the comparison of relative amount of seminal plasma used in protocols for semen freezing between these two species were the starting point for the development of the present study, taking that the physiology need of spermatozoa from each species is different.

Thus, the general aim of this study was to determine methods which could improve rates of equine seminal freezing/thawing, mainly of animals that present impaired freezability.

The specific objective is to compare the spermatic viability after freezing/thawing of equine semen. For this purpose we analyzed the individual variations among different treatments: Seminal plasma with high concentration of proteins containing molecular weight up to $10 \mathrm{kDa}$; Seminal plasma containing proteins of molecular weight with less than $10 \mathrm{kDa}$; and total seminal plasma, was used as control.

\section{MATERIALS AND METHODS}

Eight stallions of different breeds was divided in two stages. In the first stage, semen collection was accomplished in order to concentrate seminal plasma while in the second stage the objective was freezing the spermatozoa that was accomplished, by comparing conventional freezing using complete seminal plasma, seminal plasma containing ten-fold concentrated proteins of high molecular weight, and seminal plasma containing low molecular weight proteins. Six ejaculated from each animal were collected using a Hannover model artificial vagina, beeing the first ejaculate used to concentrate seminal plasma while the other were analyzed post-thawing.

\section{Collection and concentration of seminal plasma}

After semen collection, gelatinous portion was removed from ejaculated using a pipette Pasteur, and then was filtrated in sterile gauze for removal of sludges. Ejaculates were identified and maintained in ice for transport to laboratory. The semen was centrifuged at 750 $\mathrm{x} \mathrm{g}$ for 10 minutes at $4^{\circ} \mathrm{C}$ and, soon afterwards, it was submitted to the ultra centrifugation for 40 minutes at $100.000 \mathrm{x} \mathrm{g}$ at $4^{\circ} \mathrm{C}$ to avoid sludges or sperm cells. After ultra centrifugation, it was added PMSF $10 \mathrm{mM}\left(\right.$ Sigma $\left.^{\circledR}\right)$ and benzamidine $10 \mathrm{mM}$ (Sigma $\left.{ }^{\circledR}\right)$ to seminal plasma final volume, in order to inhibit the action of proteases.

Seminal plasma of each animal was ten-fold concentrated, by using the AMICON protein concentrator, which has the property of maintaining the osmotic characteristics of solution. It was used the filtrating membrane AMICOM 10000, that retains proteins with molecular weight superior to $10 \mathrm{kDa}$, and approximate nitrogen pressure of 3 bar. During whole process, samples were maintained at $4^{\circ} \mathrm{C}$. After the treatment, the material retained by the membrane was aliquoted in $2 \mathrm{~mL}$ and stored at $-70^{\circ} \mathrm{C}$, while the filtrated material was aliquoted in $10 \mathrm{~mL}$ and also stored at $-70^{\circ} \mathrm{C}$, until the use.

\section{Processing for freezing}

The spermatic concentration of the samples was determined through a Newbauer chamber. Semen was divided in three conical tubes so that, being ressuspended in freezing extender, we could obtain a concentration of 100 million spermatozoa $/ \mathrm{mL}$. Semen was diluted in 1:2 ratio with Glucose-EDTA extender (MARTIN et al, 1979) modified by SOUZA et al. (2001) containing $12 \mathrm{~g}$ glucose; $0.240 \mathrm{~g}$ sodium carbonate; $0.740 \mathrm{~g}$ EDTA; $0.750 \mathrm{~g}$ sodium 
citrate $2 \mathrm{H}_{2} \mathrm{O} ; 0.8 \mathrm{~g} \mathrm{AGROVET}^{\circledR}$ (Novartis); $200 \mathrm{~mL}$ distilled water q.s.p. (SOUZA et al, 2001). Then, it was centrifuged at $400 \mathrm{x} \mathrm{g}$, for 10 minutes, at $20^{\circ} \mathrm{C}$.

After centrifugation, we identified tubes according to the treatment. In control samples, supernatant was removed leaving $10 \%$ of seminal plasma with pelleted of cells in the tube. In the another tube, seminal plasma was fully removed and it was added $10 \%$ of seminal plasma with high molecular weight proteins, ten-fold concentrated. In the third tube, seminal plasma was totally removed and added $10 \%$ of seminal plasma with low molecular weight proteins.

Resuspension of the pellet containg spermatozoa was performed by addition of freezing extender $(50 \mathrm{~mL}$ lactose $11 \%, 25 \mathrm{~mL}$ glucose-EDTA, $20 \mathrm{~mL}$ egg yolk in natura; 5 $\mathrm{mL}$ glicerol; $0.5 \mathrm{~mL}$ Equex® - Farmácia, Orvus et paste) in order to attain a $100 \times 10^{6}$ cells/mL concentration.

After semen was resuspended in freezing extender, it was bottled properly in $0.5 \mathrm{~mL}$ straws justly identified. Straws were enclosed with polyvinylic alcohol and, then, they were placed in rest for 20 minutes at $4^{\circ} \mathrm{C}$. Following, straws were stored in liquid nitrogen steam, 4 $\mathrm{cm}$ above the level of this cryogenic for 10 minutes, and later, they were immersed in $\mathrm{N}_{2}$ and, then, stored at $-196^{\circ} \mathrm{C}$.

After thawing, total and progressive motility were analyzed by software Ceros version 10.8 from Hamilton Torn Research (HTR). Integrity of spermatozoa plasmatic membrane were analyzed by Giemsa Tripan blue method of coloration (DIDION et al, 1989). In order to consider the effect variation in freezability among stallions we used DMS test $(p<0,05)$.

\section{RESULTS}

The individual variation of semen freezability among stallions was observed in the present study. For this reason we analyzed the effect of treatments in freezing of each stallion using the DMS test (table 1). The treatment that used concentrated seminal plasma ([PSE]) induced an improvement on the studied parameters when compared with the other treatments in semen freezing of stallions 1 and 2. Semen freezing of stallions 4, 5 and 6 showed that the treatment using the low molecular weight fraction of seminal plasma (Ptn $\downarrow P M)$ was reduced, compared to the treatments.

Table 1: Average of total motility post-thawing of stallions submitted to three treatments: conventional (control), concentrated seminal plasma ([PSE]) and low molecular weight fraction of seminal plasma of (PtnPM).

\begin{tabular}{lcccccccc} 
& \multicolumn{8}{c}{ Stallion $^{1}$} \\
\cline { 2 - 9 } Treatment & 1 & 2 & 3 & 4 & 5 & 6 & 7 & 8 \\
\hline Control & $17.2^{\mathrm{b}}$ & $7.6^{\mathrm{b}}$ & $4.8 \mathrm{a}^{\mathrm{b}}$ & $50.8^{\mathrm{a}}$ & $18.2^{\mathrm{a}}$ & $27.6^{\mathrm{a}}$ & $9.8 \mathrm{a}^{\mathrm{b}}$ & $5.2^{\mathrm{b}}$ \\
[PSE] & $39.4^{\mathrm{a}}$ & $18.4^{\mathrm{a}}$ & $9.8^{\mathrm{a}}$ & $55.0^{\mathrm{a}}$ & $20.2^{\mathrm{a}}$ & $32.0^{\mathrm{a}}$ & $13.6^{\mathrm{a}}$ & $10.6^{\mathrm{a}}$ \\
ptn $\downarrow$ PM & $16.8^{\mathrm{b}}$ & $9.6^{\mathrm{b}}$ & $2.8^{\mathrm{b}}$ & $43.0^{\mathrm{b}}$ & $9.4^{\mathrm{b}}$ & $15.2^{\mathrm{b}}$ & $5.6^{\mathrm{b}}$ & $6.2 \mathrm{a}^{\mathrm{b}}$
\end{tabular}

${ }^{1}$ Means in column, followed by different letters, are different by DMS test $(\mathrm{P}<0.05)$

When using $30 \%$ of seminal motility post-thawing as index of good freezability (SAMPER, 1995) an increase was verified in the percentage of stallions which presented good freezability, when semen was frozen with seminal plasma containing high molecular weight proteins ten-fold concentrated. The percentage of stallion semen that presentied good freezability increased from 12.5 to $37 \%$ when freezing added with seminal plasma with high molecular weight proteins ten-fold concentrated. 
Also, we observed through DMS test that there was an additive effect between stallion and treatment $(\mathrm{F}<0.05)$ in the total motility analysis. This effect was not observed in the progressive motility analysis, occurring only the effect of treatment $(p>0.05)$ when the concentrated seminal plasma treatment ([PSE]) was up to the other treatments and control was more than the treatment that used the low molecular weight fraction of seminal plasma (Ptn $\downarrow P M)$ according to table 2 .

Table 2: Average of progressive motility post-thawing of stallions submitted to three treatments: conventional (controls), concentrated seminal plasma ([PSE]) and low molecular weight fraction of seminal plasma (Ptn $\downarrow$ PM).

\begin{tabular}{ll}
\hline Treatment & Mean $^{1}$ \\
\hline Control $(\mathrm{n}=40)$ & $5.18^{\mathrm{b}}$ \\
[PSE] $(\mathrm{n}=40)$ & $7.03^{\mathrm{a}}$ \\
$\mathrm{ptn} \downarrow \mathrm{PM}(\mathrm{n}=40)$ & $3.75^{\mathrm{c}}$ \\
\hline CV $(\%)$ & 41.4 \\
\hline
\end{tabular}

${ }^{1}$ Means in column, followed by different letters, are different by DMS test $(\mathrm{P}<0.05)$

The table 3 shows the analysis of acrosomal membrane integrity by Giemsa Trypan Blue coloration.

Table 3: Percentage of mean of spermatozoa with intact membrane and acrosomal degeneration analyzed by Giemsa-Trvpan Blue coloration method $(n=8)$, for treatments: conventional (control), concentrated seminal plasma ([PSE]) and low molecular weight fraction of seminal plasma (Ptn $\downarrow$ PM).

\begin{tabular}{lcc}
\hline Treatment & Intact spermatozoa $(\%)$ & Degenerated spermatozoa (\%) \\
\hline Control & 65 & 35 \\
[PSE] & 78 & 22 \\
ptn $\downarrow$ PM & 62 & 38 \\
\hline
\end{tabular}

In table 3, it can be verified a tendency of larger percentage of entire spermatozoa for the group treated with concentrated seminal plasma, followed by control and low molecular weight protein fraction of seminal plasma.

\section{DISCUSSION}

Seminal plasma ten-fold concentrated used in this study contained proteins of molecular weight above to $10 \mathrm{kDa}$, showing that its addition in processing of equine semen promoted a beneficial effect on the freezing. The fraction of seminal plasma composed by low molecular weight proteins, that which are less than $10 \mathrm{kDa}$, was not beneficial to the sperm cells when added during cryopreservation, corroborating the observations that low molecular weight proteins reduce motility and cause damages in the membrane integrity of spermatozoa (AL-SOMAI et al, 1994a; AL-SOMAI et al, 1994b).

This beneficial action of addition of concentrated seminal plasma is better in motility of stallions of low freezability probably due to the low concentration of proteins in the native seminal plasma. Stallions that present good freezability, presented protein concentration that justifies them as good freezers (TROEDSSON, 1999), making the addition of the plasma seminal 10-fold concentrate not to present an outstanding improvement in its freezability. 
It is supposed that the beneficial effect of seminal plasma in the motility after freezing and thawing extends to the spermatic resistance in the female genital tract, increasing its protection, due to the adsorption of proteins in the membrane of spermatozoa, as a mechanism that prevent the recognition by female immune cells for those elimination (SAMPER, 1998). Based on this hypothesis it is expected that the inseminating dosage using equine semen with concentrated seminal plasma is smaller than the inseminating dosage conventionally used, since this spermatozoa is more protected by seminal plasma against injuries from female immunological system than spermatozoa frozen by the traditional method, became an alternative to improve the cryopreservation protocols described by WOELDERS et al., (1997) for that the inseminating dosage can be decreased and by GRAHAM et al., (1996) who described an enhanced freezability of semen from stallions that present a bad freezing.

The beneficial effect of seminal plasma in freezing/thawing processing of spermatozoa was described in different species, corroborating that verified in the present work, where it was used equine ten-fold concentrated seminal plasma in the processing for equine spermatozoa cryopreservation.

Considering data obtained in the present study in which we described that better acrosomal membrane integrity of the group treated with ten-fold concentrated seminal plasma and a improved motility, also observed in this group, we can proposed that there is a beneficial action from concentrated seminal plasma to the cryopreservation of equine spermatozoa.

Results of this research allow study us to propose proposing the existence of a differentiated beneficial action from concentrated seminal plasma in the equine semen cryopreservation according to its freezability.

\section{REFERENCES}

AMANN, R. P., PICKETT, B. W. Principles of cryopreservation of stallion spermatozoa. Journal of Equine Veterinary Science. v.7, p.145-173, 1987.

AURICH, J. E. et al. Seminal plasma affects membrane integrity and motility of equine spermatozoa after cryopreservation. Theriogenology, v.46, p.791 -797, 1996.

AL-SOMAI, N. et al. Low molecular weight components in bovine semen diffusate and their effects on motility of bull sperm. Reproduction and Fertility. v.6 p.165-171, 1994a.

AL-SOMAI, N. et al. Anionic and cationic components from protein aggregates in bovine seminal plasma and their effects on sperm motility. Molecular Reproduction, v. 39, p.328336, 1994b.

BARRIOS, B. et al. Seminal plasma proteins revert the cold-shock damage on ram sperm membrane. Biology of Reproduction, v.63, p.1531-1537, 2000.

CATT, S. L. et al. Assessment of ram and boar spermatozoa during cell-sorting by flow cytometry. Reproduction in Domestic Animal, v.32, p.251-258, 1997.

DIDION, B. A. et al. Staining procedures to detect viability and the true acrosome reaction in spermatozoa of various species. Gamete Research, v.22, p.51-57, 1989.

GARCÍA, M. A.; GRAHAM, E. F. Effects of low-molecular-weight fractions (LMWF) from 
Fagundes, B.; van Tilburg, M.F.; Souza, G.V.; Caiado, J.R.C.; Barreto, M.A.P.; Silva, J.F.S.

Effect of addition of concentrated proteins and seminal plasma low of addition of concentrated proteins and seminal plasma low molecular

weight proteins in freezing and thawing of equine semen.

milk, egg yolk and seminal plasma on freezability of bovine spermatozoa. Cryobiology, v.24, p.429-436, 1987.

GRAHAM, J. K. Cryopreservation of stallion spermatozoa. In: Diagnostic techniques and assisted reproductive technology. Edited by E. L. Squires. Veterinary Clinics of North America, v.4(2), p.131-147, 1996.

HENAULT, M. A.; KILLIAN, G. J. Effect of homologeous and heterologous seminal plasma on the fertilizing ability of ejaculated bull spermatozoa assessed by penetration of zona-free bovine oocytes. Journal of Reproduction and Fertility, v.108, p.199-204, 1996.

KLUG, E. et al. Cryopreservation of stallion spermatozoa. Acta Veterinaria Scandinavica, v.88, p.129-135, 1992.

MARTIN, J. C. et al. Centrifugation of stallion semen and its storage in large volume straws. Journal of Reproduction and Fertility, v.27, p.47-51, 1979.

MAXWELL, W. M. C.; JOHNSON, L. A. Membrane status of boar spermatozoa after coolinq or crvopreservation. Theriogenology, v.48, p.2209-2219, 1999.

PURSEL, V. G.; JOHNSON, L. A. Freezing of boar spermatozoa fertilizing capacity with concentrated semen and a new thawing procedure. Journal Animal Science, v.40, p.99-102, 1975.

RIGBY, S. et al. Administration of oxytocin immediately after insemination does not improve pregnancy rates in mares bred by fertile or subfertile stallions. Theriogenology, v.51, p.1143$1150,1999$.

SAMPER, J. C. Stallion semen cryopreservation: male factors affecting pregnancy rates. Proc Society for Theriogenology, 160-165, 1995.

SAMPER, J. C.; MORRIS, C. A. Current methods for stallion semen cryopreservation: a survey. Theriogenology, v.49(5), p.895-903, 1998.

SOUZA, G. V. et al. Comparação de antibióticos pró-análise e comerciais adicionados ao diluente seminal glicina-gema na motilidade de espermatozóides conservados a $5^{\circ} \mathrm{C}$ de garanhões. Revista Brasileira de Reprodução Animal, v.25, n.1, p.450-451, 2001.

TROEDSSON, M. H. T. Uterine clearance and resistance to persistent endometritis in the mare. Theriogenology, v.52, p.461-471, 1999.

VIDAMENT, M. et al. Equine frozen semen freezability and fertility results. Theriogenology, v.48, p.907-917, 1997.

WOELDERS, J. H. Fundamentals and recent development of cryopreservation of bull and boar semen. Vet. Quart. 19, p.135-138, 1997. 